\title{
Air and root medium temperature and the rooting of chrysanthemum and rose cuttings
}

\author{
EDWARD BOROWSKI ${ }^{1}$, PAUL HAGEN 2 , ROAR MOE 2
}

1 Institute of Natural Principles of Plant Production, Agricultural Academy, Akademicka 15, 20-934 Lublin, Poland

2 Department of Floriculture and Greenhouse Crops, Agricultural University of Norway N-1432 Aas-NLH

(Received: February 16, 1986)

\begin{abstract}
Cuttings of the chrysanthemum cultivar 'Horim' and rose cultivar 'Garnette' were rooted at $21^{\circ} \mathrm{C}, 24^{\circ} \mathrm{C}, 27^{\circ} \mathrm{C}$ root temperature in a factorial combination with $15^{\circ} \mathrm{C}, 18^{\circ} \mathrm{C}$ and $21^{\circ} \mathrm{C}$ air temperature. In each of the air and root temperatures, rose cuttings from different positions of the flower shoot were rooted. The effects of air and root temperatures and their interactions on root formation of chrysanthemum and rose cuttings were studied. Increasing the air temperature from $15^{\circ} \mathrm{C}$ to $21^{\circ} \mathrm{C}$ accelerated rooting and distinctly increased the number of roots per cutting on both plants. Higher root temperatures $\left(24^{\circ} \mathrm{C}, 27^{\circ} \mathrm{C}\right)$ had a favorable influence on the rate of the rooting process but did not enhance the number of formed roots. Increasing both temperatures significantly increased the growth of the roots and their fresh and dry weight. An adverse effect of the root temperature was noticed on the breaking and growth of rose buds. Increasing the temperature from $21^{\circ} \mathrm{C}$ to $27^{\circ} \mathrm{C}$ strongly decreased the percentage of breaking buds and their growth. The results are discussed from the point of view of the influence air temperature on the contents of growth substances in the cuttings.
\end{abstract}

\section{INTRODUCTION}

Early work on new propagation methods of potted roses showed that increasing the temperature of the environment from $15^{\circ} \mathrm{C}$ to $27^{\circ} \mathrm{C}$ had a favorable effect on the rooting of rose cuttings (Mo e, 1973). Similar effects of increasing temperatures (in the appropriate range) on rooting of cuttings have been reported for rhododendrons (Whalle y and Loach, 1977), Euphorbia pulcherrima (Gislerød, 1975), Camella japonica and Chrysanthemum morifolium (O o is hi et al., 1978), Juniperus horizontalis ( $\mathrm{L}$ a $\mathrm{n} \mathrm{ph}$ e a r and $\mathrm{M}$ e a h l, 1967) and plum (H o w a r d and $\mathrm{Nahlawi}$ 1969). Since the majority of these investigations entail- 
ed the influence of cnvironmental or root temperatures without a constant air temperature, it cannot be deduced whether the above-mentioned effect of temperatures on rooting of cuttings was mediated by the root-, air temperatures, or by interactions of the two.

Therefore, in the present paper we report the effects of air and root temperatures and their interactions on root formation of chrysanthemum and rose cuttings. In an experiment with rose cuttings we also studied the effect of the position of the cuttings.

\section{MATERIALS AND METHODS}

Chrysanthemum plants of the cultivar 'Horim' and of the rose cultivar 'Garnette' were grown at $18^{\circ} \mathrm{C}$ in a greenhouse. The chrysanthemum stock plants were given a long day $(24 \mathrm{~h})$ with incadescent lamps. The rose stock plants were grown under natural lighting condition.

The cuttings were taken from the chrysanthemum stock plants at about 4 week intervals and only once from the rose stock plants. The chrysanthemum cuttings were about $5 \mathrm{~cm}$ in lenght and had 3-4 fully developed leaves. The rose cuttings consisted of a piece of the stem with one 5-leaflet leaf. They were taken from stock plants having buds with visible flower colour. In the experiment, cutings were used from positions 5,6 and 7 , counting from the bud. The cuttings of both plants were planted in $1 \mathrm{~cm}$ thick insulation plates (isopor) with holes for the cuttings. The plates floated in $15 \mathrm{~cm}$ deep plastic trays filled halfway with distilled water. The trays were placed in threes in air-conditioned rooms (phytotron) with good control of temperature and air humidity, where temperatures of $15^{\circ} \mathrm{C}, 18^{\circ} \mathrm{C}$ and $21^{\circ} \mathrm{C}\left( \pm 1^{\circ} \mathrm{C}\right)$ were kept. Each of the 3 trays placed in one air conditioned room had a different water temperature: $21^{\circ} \mathrm{C} ; 24^{\circ} \mathrm{C} ; 27^{\circ} \mathrm{C}\left( \pm 0.5^{\circ} \mathrm{C}\right)$. Thus, in the experiments with chrysanthemum and rose cuttings air temperatures of $15^{\circ}, 18^{\circ}, 21^{\circ} \mathrm{C}$ and root temperatures of $21^{\circ}, 24^{\circ}, 27^{\circ} \mathrm{C}$ in all combinations were maintained. Additionally, in the experiment with rose cuttings, each of the 9 trays contained cuttings from three positions, 18 pieces from each, so each tray contained 54, also 54 cuttings were contained in one tray in the experiment with chrysanthemum cuttings. Adequate water temperature in the trays was maintained by circulation of warm water through plastic tubules on the bottom of the trays. During the rooting period, the water in both experiments was aerated using special air pumps. The trays were covered with a film of white polyethylene shut $50 \mathrm{~cm}$ above the cuttings, in order to obtain lower irradiation and higher, about $90 \%$ f.w.c., air humidity. Each treatment was run in duplicate in the experiment with chrysanthemums and one replication in the experiment with rose cuttings. 
The chrysanthemum cuttings were rooted for 2 weeks, the rose cuttings for 3 weeks. During the root formation period, the numbers of rooted cuttings were counted and the percentage was calculated. If not otherwise stated, numbers of roots per cutting, length of the longest root, and fresh and dry weight of roots for both plants were recorded at the end of the rooting period. Additionally in the experiment with rose cuttings, the percentage of breaking buds, their growth and dry weight were also recorded. All parameters were analysed statistically, using the doubly cross classification system and Tuke's range of confidence.

\section{RESULTS}

The rooting of chrysanthemum and rose cuttings was influenced by the air and root temperatures (Figs. 1,2). Together with an increase in air and root temperature there was a clear increase in the rate of rooting. However, the influence of air temperature on the rate of rooting of cuttings was more distinct than that of root temperature. The chrysanthemum cuttings rooted at higher air temperatures $\left(18^{\circ} \mathrm{C}\right.$ and $\left.21^{\circ} \mathrm{C}\right)$ reached full rooting 2-3 days earlier (depending on root temperatures), than cuttings rooted at $15^{\circ} \mathrm{C}$ (Fig. 1). The rose cuttings rooted at $100 \%$

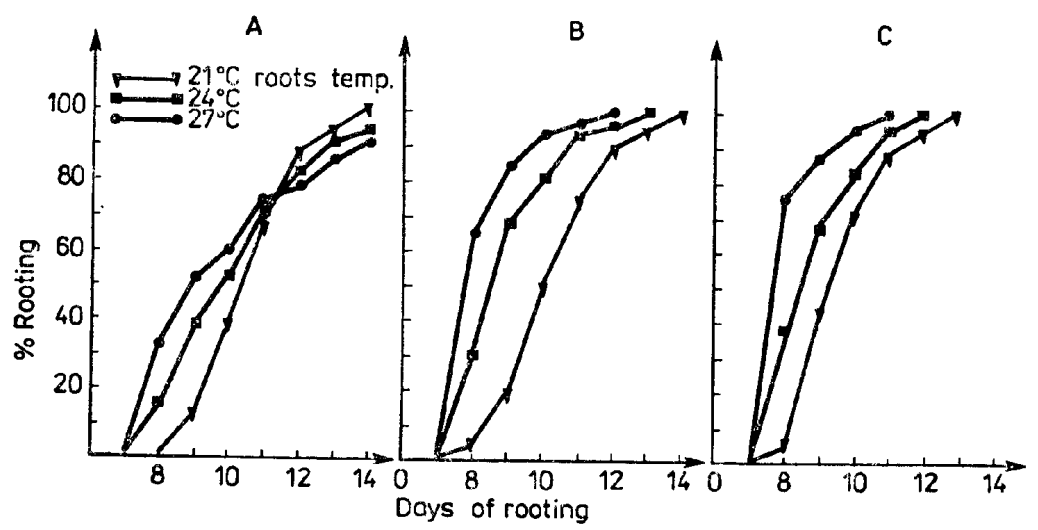

Fig. 1. The effect of air and root temperatures on the percentage of rooted chrysanthemum cuttings after planting in a phytotron at air temperature. A $15^{\circ} \mathrm{C} ; \mathrm{B}-18^{\circ} \mathrm{C} ; \mathrm{C}-21^{\circ} \mathrm{C}$

when higher air temperatures $\left(18^{\circ} \mathrm{C}\right.$ and $\left.21^{\circ} \mathrm{C}\right)$ cooperated with the highest root temperature $\left(27^{\circ} \mathrm{C}\right)$. At $15^{\circ} \mathrm{C}$ air temperature and $21^{\circ} \mathrm{C}$ root temperature, the average rooting-percentage did not exceed 50 (Fig. 2). Positions of the rose cuttings had a marked influence on their rate of rooting only at higher air $\left(18^{\circ} \mathrm{C}, 21^{\circ} \mathrm{C}\right)$ and root temperatures $\left(24^{\circ} \mathrm{C}, 27^{\circ} \mathrm{C}\right)$. At $18^{\circ} \mathrm{C}$ air temperature and $27^{\circ} \mathrm{C}$ root temperature, the best rate of 


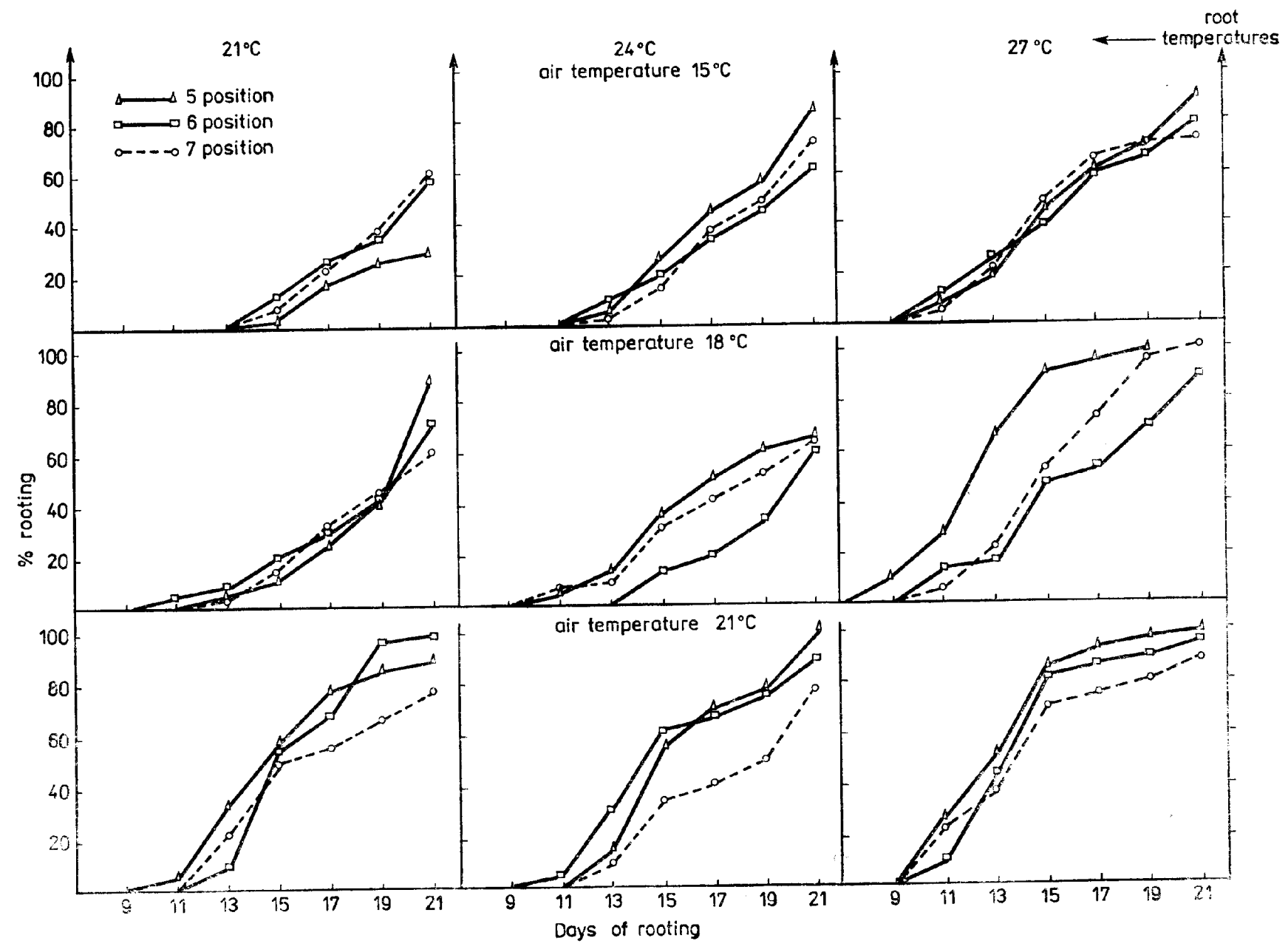

Fig. 2. The effect of air and root temperatures as well as that of position of cuttings on the percentage of rooted rose cuttings after planting in a phytotion 
initiating roots was shown by, from position 5. Increasing air temperature to $21^{\circ} \mathrm{C}$ resulted in a good rate of rooting cuttings from position 5 and 6 (Fig. 2).

The number of roots per cutting, length of the longest root and their fresh and dry weight after a rooting period lasting 2 and 3 weeks for chrysanthemum and rose cuttings respectively, are shown in Table 1 and 2. Furthermore, the appearance of rooted cuttings on both plants, is shown in Figures 3 and 4 . The mean number of roots per cutting of the chrysanthemum and rose was increased only with increasing air temperature. The influence of root temperature on the number of roots formed by both plants appeared to be nonsignificant (Tables 1, 2). The length of roots, however, increased with an increase in air and root temperatures. Also, interaction between those two factors had a positive effect on the growth of chrysanthemum roots (Table 1). Increasing air and root temperature during the rooting period resulted in enhanced fresh and dry weight of roots per cutting of both plants. The position of the rose cuttings did not have a significant influence on the number of formed roots or on their growth, therefore this factor was not taken into consideration. Tables 3 and 4 show the effect of air and root temperature as well as that of the position of rose cuttings on bud breaking and their growth. Increasing the root temperature from $21^{\circ} \mathrm{C}$ to $27^{\circ} \mathrm{C}$ independently of air temperature or position of the cutting on stock plants, decreased the percentage bud breaking from 58.6 to 27.1 respectively. The percentage of bud breaking also depended on the position of the cutting, but was not dependent on air temperature. Cuttings taken from position 5 had a markedly higher mean percentage bud breaking (62.9) than those from position $6(37.0)$ or 7 (27.8) (Table 4). Further it is shown in Table 3 that the growth of the buds from all of the positions used was strongly decreased with increasing root temperature. The dry weight of the buds depended particularly on the position of the cuttings. The buds on cuttings from position 5 had the highest dry weight, the lowest was shown by those from position 7 .

\section{DISCUSSION}

Increasing the air temperature from $15^{\circ} \mathrm{C}$ to $21^{\circ} \mathrm{C}$ markedly increased the number of roots per chrysanthemum and rose cutting. Different root temperatures did not have any effect on the number of initiated roots. Some authors also reported that increasing the environmental temperature in the appropriate range had a positive effect on the rooting of rose cuttings (Moe, 1973) and cuttings of other plants (O o is hi et al., 1978; W halle y and Lo a c h, 1977; G is le rød, 1975; How a d and $\mathrm{Nahlawi}$ 1969; Lan phear and $\mathrm{Meahl}$, 1967). Our results, how- 

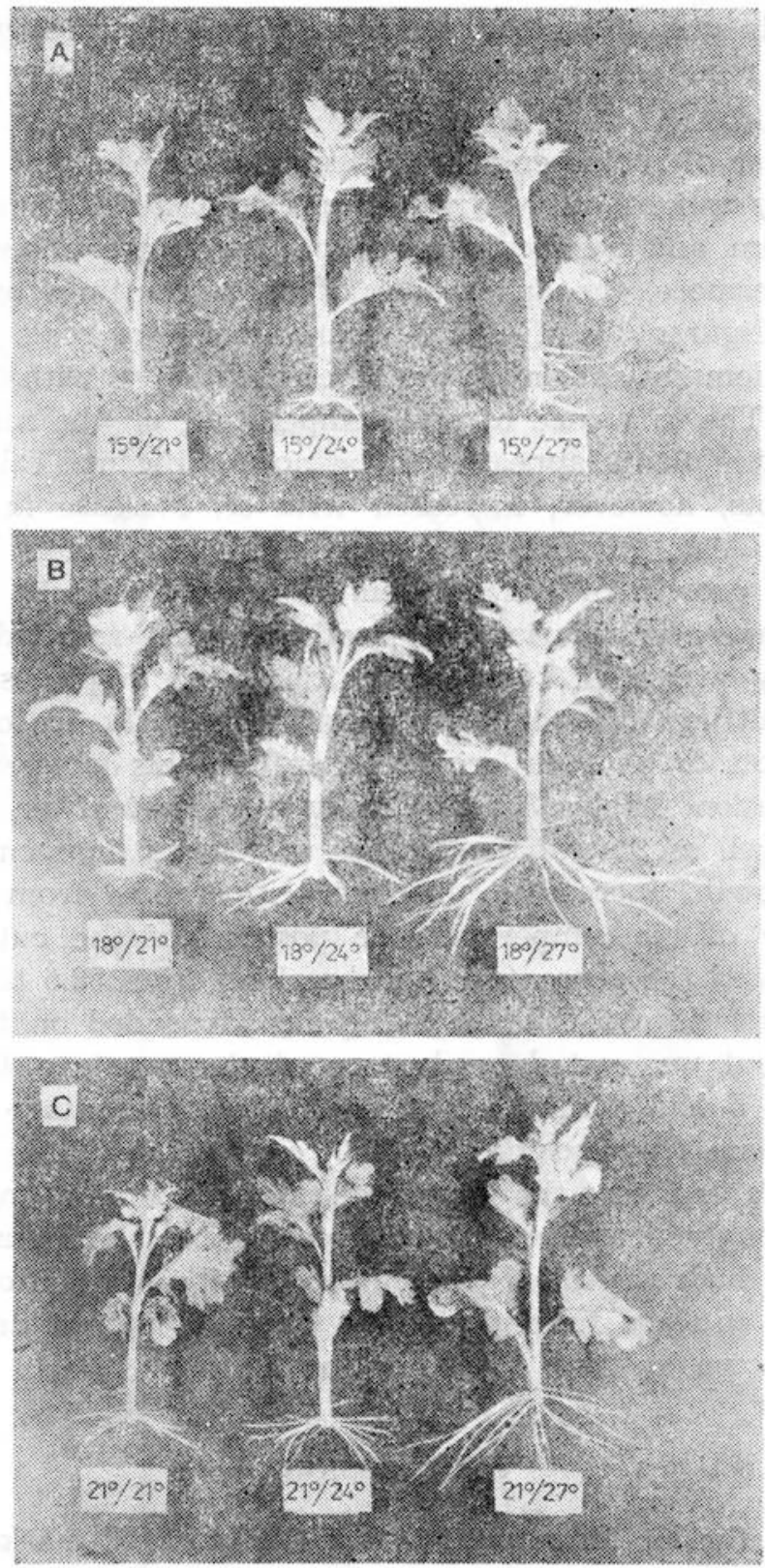

Fig. 3. The effect of air and root temperatures on the rooting of chrysanthemum cuttings. Rooted cuttings after two weeks at $\mathrm{A}-15^{\circ} \mathrm{C} ; \mathrm{B}-18^{\circ} \mathrm{C} ; \mathrm{C}-21^{\circ} \mathrm{C}$; air temperature and root temperature, $21^{\circ} \mathrm{C}, 24^{\circ} \mathrm{C}, 27^{\circ} \mathrm{C}$, respectively

ever, are difficult to compare with those cited above, because we studied the effects of air and root temperatures on rooting of the cuttings separately. 

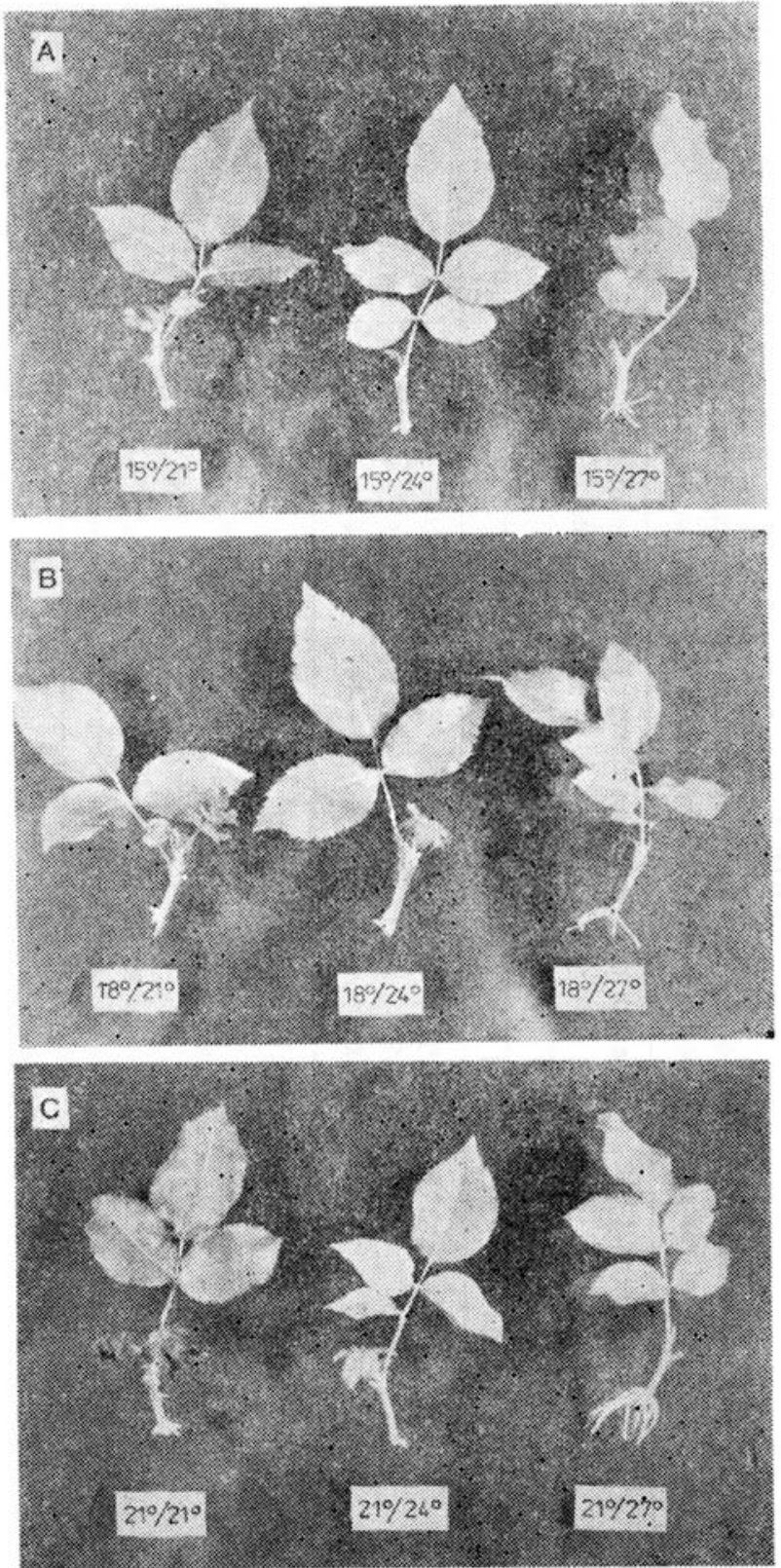

Fig. 4. The effect of air and root temperatures on the rooting of rose cuttings. Rooted cuttings after three weeks at $\mathrm{A}-15^{\circ} \mathrm{C} ; \mathrm{B}-18^{\circ} \mathrm{C} ; \mathrm{C}-21^{\circ} \mathrm{C}$; air temperature and root temperature, $21^{\circ} \mathrm{C}, 24^{\circ} \mathrm{C}, 27^{\circ} \mathrm{C}$, respectively

The present results very clearly show that the main effect on the number of initiated roots was exerted by the air temperature. The influence of air temperature on adventitious root formation is explained 


\section{Table 1}

The effect of air and root temperatures during the rooting of chrysanthemum cuttings on the number of produced roots, root length, and fresh and dry weights of roots after a rooting period of 2 weeks in a phytotron under natural light*

\begin{tabular}{|c|c|c|c|c|c|c|c|c|c|c|c|c|}
\hline \multirow{3}{*}{$\begin{array}{c}\text { Air } \\
\text { temperature } \\
{ }^{\circ} \mathrm{C}\end{array}$} & \multicolumn{3}{|c|}{$\begin{array}{l}\text { Roots per } \\
\text { cutting }\end{array}$} & \multicolumn{3}{|c|}{$\begin{array}{l}\text { Length of longest root } \\
\qquad \mathrm{cm}\end{array}$} & \multicolumn{3}{|c|}{$\begin{array}{c}\text { Fresh weight of roots } \\
\text { mg/plant }\end{array}$} & \multicolumn{3}{|c|}{$\begin{array}{l}\text { Dry weight of roots } \\
\mathrm{mg} / \text { plant }\end{array}$} \\
\hline & \multicolumn{12}{|c|}{ root temperature ${ }^{\circ} \mathrm{C}$} \\
\hline & 21 & 24 & 27 & 21 & 24 & 27 & 21 & 24 & 27 & 21 & 24 & 27 \\
\hline 15 & 26.1 & 24.7 & 25.8 & 1.8 & 2.8 & 4.3 & 45 & 97 & 141 & 5 & 9 & 13 \\
\hline 18 & 29.1 & 28.3 & 30.1 & 2.5 & 6.1 & 7.2 & 93 & 205 & 246 & 8 & 17 & 23 \\
\hline 21 & 36.5 & 32.7 & 32.8 & 4.2 & 5.1 & 7.0 & 147 & 164 & 240 & 14 & 15 & 22 \\
\hline
\end{tabular}

Significance of main effects and interactions

roots per cutting

Air temp.

Root temp.

Air temp. $\times$ root temp. root length

$* *$
NS
NS fresh weight of roots dry weight of roots

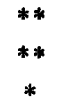

*

NS

* - significant at $0.05 ; * *$ significant at 0.01 ; NS - nonsignificant. 


\section{Table 2}

The effect of air and root temperatures during the rooting of rose cuttings on the number of produced roots, root length, and fresh and dry weights of roots after a rooting period of 3 weeks in a phytotron under natural light*

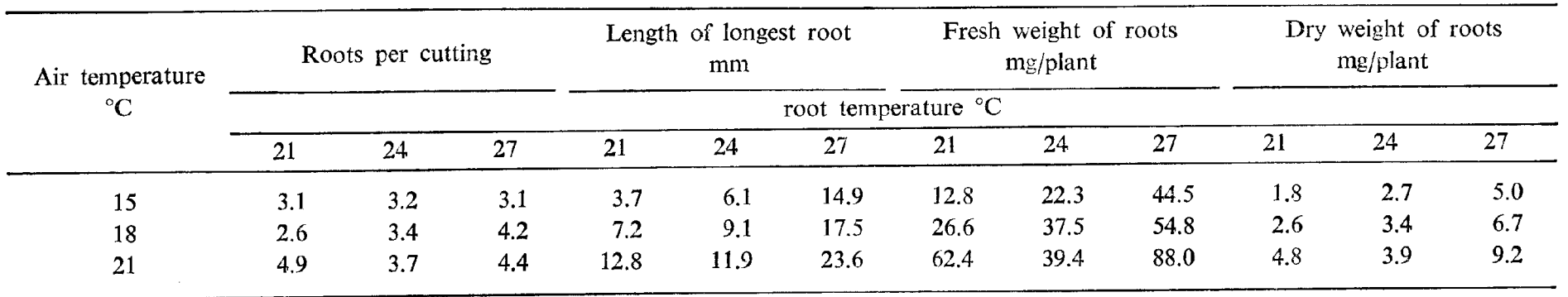

Significance of main effects and interactions

Air temp.

Root temp.

Air temp. $\times$ root temp. root length

$* *$

**

NS fresh weight of roots

dry weight of roots

**

NS

NS

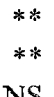

NS
**

NS

Explanations as in Table 1 
Ta ble 3

The effect of air and root temperatures and of the position of the cuttings on the bud breaking percentage, bud growth and dry weight after a rooting period of 3 weeks of rose cuttings in a phytotron under natural light

\begin{tabular}{|c|c|c|c|c|c|c|c|c|c|c|}
\hline \multirow{3}{*}{$\begin{array}{l}\text { Air temp. } \\
{ }^{\circ} \mathrm{C}\end{array}$} & \multirow{3}{*}{$\begin{array}{l}\text { Root } \\
\text { temp. } \\
{ }^{\circ} \mathrm{C}\end{array}$} & \multicolumn{3}{|c|}{$\begin{array}{c}\text { Bud breaking } \\
\%\end{array}$} & \multicolumn{3}{|c|}{$\begin{array}{l}\text { Bud growth } \\
\text { cm }\end{array}$} & \multicolumn{3}{|c|}{$\begin{array}{l}\text { Dry weight of buds } \\
\mathrm{mg}\end{array}$} \\
\hline & & \multicolumn{9}{|c|}{ position of cuttings } \\
\hline & & 5 & 6 & 7 & 5 & 6 & 7 & 5 & 6 & 7 \\
\hline \multirow{4}{*}{15} & 21 & 77.8 & 66.7 & 50.0 & 1.7 & 1.7 & 1.2 & 55.9 & 46.9 & 25.9 \\
\hline & 24 & 55.5 & 38.9 & 22.2 & 1.3 & 1.5 & 0.8 & 57.2 & 48.3 & 17.5 \\
\hline & 27 & 33.3 & 22.2 & 16.7 & 1.2 & 0.9 & 0.5 & 60.2 & 27.7 & 17.0 \\
\hline & 21 & 88.9 & 50.0 & 44.4 & 2.0 & 1.6 & 2.0 & 54.2 & 52.0 & 49.0 \\
\hline \multirow[t]{3}{*}{18} & 24 & 88.9 & 22.2 & 33.3 & 2.1 & 1.3 & 1.5 & 80.3 & 47.0 & 52.2 \\
\hline & 27 & 55.5 & 22.2 & 16.7 & 1.5 & 0.6 & 0.6 & 67.4 & 29.8 & 31.1 \\
\hline & 21 & 66.7 & 55.5 & 27.8 & 1.8 & 2.0 & 1.5 & 77.1 & 60.2 & 44.9 \\
\hline \multirow[t]{2}{*}{21} & 24 & 55.5 & 38.9 & 22.2 & 1.8 & 1.7 & 1.3 & 68.8 & 64.5 & 50.7 \\
\hline & 27 & 44.4 & 16.7 & 16.7 & 1.1 & 0.7 & 0.6 & 61.7 & 40.5 & 25.2 \\
\hline
\end{tabular}

Significance of main effects and interactions bud growth

Air temp.

Root temp.

Position

Air temp. $\times$ root temp.

Air temp. $\times$ position

Root temp. $\times$ position

Air temp. $\times$ root temp. $\times$ position

NS
$* *$
NS
NS
NS
NS
NS

dry weight of buds

Explanations as in Table 1. 
Ta b le 4

Separate effect of air and root temperatures as well as that of positions of rose cuttings on mean percentage of bud breaking

\begin{tabular}{cccccc}
\hline $\begin{array}{c}\text { Air } \\
\text { temp. } \\
{ }^{\circ} \mathrm{C}\end{array}$ & $\begin{array}{c}\text { Bud } \\
\text { breaking } \\
\%\end{array}$ & $\begin{array}{c}\text { Root } \\
\text { temp. } \\
\%\end{array}$ & $\begin{array}{c}\text { Bud } \\
\text { breaking } \\
\%\end{array}$ & $\begin{array}{c}\text { Position } \\
\%\end{array}$ & $\begin{array}{c}\text { Bud } \\
\text { breaking } \\
\%\end{array}$ \\
\hline 15 & 42.6 & 21 & 58.6 & 5 & 62.9 \\
18 & 46.9 & 24 & 41.9 & 6 & 37.0 \\
21 & 38.3 & 27 & 27.1 & 7 & 27.8 \\
\hline
\end{tabular}

by the role of air temperature in changes of the level of endogenous auxins and other growth substances. Heide (1967) and Moe (1971) reported that the level of auxins, but $\mathrm{Zies} \mathrm{l}$ in and $\mathrm{H}$ alevy (1976) that also that of gibberellins, was much higher in extracts from shoots grown at a high temperature than in shoots grown at a low temperature. Simultaneously, it was shown by $\mathrm{Sk}$ a r peid (1951) and Eriksen (1968) for rose cuttings and by $\mathrm{H}$ eide (1967), Eliassom (1980), Alt. $\mathrm{man}$ and Wareing (1975), $\mathrm{Nanda}$ et al. (1971) for other cuttings, that a high level of auxin markedly promoted root formation. $\mathrm{H}$ a n s e $\mathrm{n}$ (1976) demonstrated that also gibberellic acid induced root formation in pea cuttings. Since young leaves have been found to be the principal source for both auxins and gibberellins (J a cobs and Morrow, 1957; $\mathrm{Jones}$ and Phillips, 1966; Jacobs, 1962), it is possible that in the experiments carried out at higher air temperatures, the leaves of cuttings of both plants produced more auxins than those at lower air temperatures. Presumably, therefore, the chrysanthemum and of rose cuttings at higher air temperatures reached full rooting earlier (Figs. 1, 2) and initiated more roots than those at lower temperatures (Tables $1,2)$.

The growth of the roots and their fresh and dry weight was increased by increasing the air and root temperatures. Thus, this might have been an indirect effect, since the root formation started earlier at high air and root temperatures than at low temperatures. Therefore the roots initiated at the higher temperatures were grown longer than the roots formed at low temperatures. On the other hand, it is well known that increasing the temperature to the optimum markedly increases the growth process of young plant parts.

The root temperature also had a significant influence on bud breaking of the rose cuttings and their growth. It can be seen from Table 2 and 3 that increasing the root temperature had an inverse effect on the growth of roots and buds. A similar adverse effect of shoot growth on root growth was observed by Eliasson (1971) on the cuttings of aspen. 
Eliasson (1971) suggested that this effect was caused by limiting the state of available carbohydrates for shoots and roots. Our results show rather that low root temperature stimulated the percentage of breaking buds and the growth of buds by inhibiting the growth process of roots. The roots therefore did not utilizate the growth substances thus causing bud breaking and their intensive growth.

Bud breaking aliso depended on the position of the cuttings. Cuttings taken from the upper positions of the shoot (posit. 5) had a high level of endogenous auxins (M o e 1971) which was sufficient for a good rate of rooting of these cuttings and a high percentage of bud breaking. This fact also indicates that the auxin content in the rose cuttings is connected with their bud breaking ability.

\section{Acknowledgments}

This research was supported by the Agricultural Research Council of Norway. A Norwegian Government Scholarship was provided to Edward Borowski by The Royal Ministry of Foreign Affairs. All financial support is highly appreciated.

\section{REFERENCES}

Altman A., Wareing P. F., 1975. The effect of IAA on sugar accumulation and basipetal transport of ${ }^{14} \mathrm{C}$-labelled assimilates in relation to root formation in Phaseolus vulgaris cuttings. Physiol. Plant. 33: 32-38.

Eliasson L., 1971. Adverse effect of shoot growth on root growth in rooted cuttings of aspen. Physiol. Plant. 25: 268-272.

Eliasson L., 1980. Interaction of light and auxin in regulation of rooting in pea stem cuttings. Physiol. Plant. 48: 78-82.

Eriksen E. N., 1968. Stiklingsformering af roser. I. Forsøg ved vaekststoff, stikketidspunkt og overvintring. Tidsskrift for Planteavl 72: 327-334.

Gislerød FI. R., 1975. The influence of temperature and water potential on rooting of poinsettia cuttings (Euphorbia pulcherrima L. Lad). Acta Hort. 54: 127-136.

Hansen J., 1976. Adventitious root formation induced by gibberelic acid and regulated by the irradiance to the stock plants. Physiol. Plant. 36: 77-81.

He i d e O. M., 1967. The auxin level of Begonia leaves in relation to their regeneration ability. Physiol. Plant. 20: 886-902.

Howard B. H., Nahlawi N., 1969. Factors affecting the rooting of plum hardwood cuttings. J. Hort. Sci. 44: 303-310.

Jacobs W. P., 1962. Longevity of plant organs: Internal factors controlling abscission. Ann. Rev. Plant Physiol. 13: 403-436.

Jacobs W. P., Morrow J. B., 1957. A quantitative study of xylem development in the vegetative shoot apex of Coleus. Amer. J. Bot. 44: 823-842.

Jones R. L., Phillips I. D. J., 1966. Organs of gibberellin synthesis in lightgrown sunflower plants. Plant Physiol. 41: 1381-1386.

Lanphear F. O., Meahl R. P., 1967. Influence of the stock plant environment on the rooting of Juniperus horizontalis Plumosus. Proc. Am. Soc. Hort. Sci. 89: $666-671$. 
Moe R., 1971. The relationship between flower abortin and endogenous auxin content of rose shoots. Physiol. Plant. 24: 374-379.

M o e R., 1973. Propagation, growth and flowering of potted roses. Acta Iort. 31: $35-51$.

Nanda K. K., Jain M. K., Shiva Malhotra, 1971. Effect of glucose and auxins in rooting etiolated stem segments of Populus nigra. Physiol. Plant. 24: $387-391$.

Ooishi A., Machida H., Hosoi T., Komatsu H., 1978. Root formation and respiration in cuttings at different temperatures. J. Japan. Soc. Hort. Sci. 47: 243-247.

Skarpeid A., 1951. Formering av veksthusroser ved stiklinger. Hovedoppgave ved Institutt for blomsterdyrking og veksthusforsøk AS - NLII.

Whalley D. N., Loach K., 1977. Effects of basal temperature on the rooting of hardy hybrid rhododendrons. Scientia Hort. 6: 83-89.

Zieslin N., Halevy A. H., 1976. Flower bud atrophy in Baccara roses. VI. The effect of environmental factors on gibberellin activity and ethylene production in flowering and non-flowering shoots. Physiol. Plant. 37: 331-335.

\section{WPŁYW TEMPERATURY SRODOWISKA KORZENI I POWIETRZA NA UKORZENIANIE SIE SADZONEK CHRYZANTEM I ROZZ}

\section{Streszczenie}

W pracy określono wpływ zróżnicowanych temperatur środowiska korzeni i powietrza na ukorzenianie się sadzonek chryzantem odmiany 'Horim' i róż odmiany 'Garnette'. Sadzonki obu roślin ukorzeniano w wodzie o temperaturze $21^{\circ} \mathrm{C}, 24^{\circ} \mathrm{C}$ i $27^{\circ} \mathrm{C}\left( \pm 0.5^{\circ} \mathrm{C}\right)$, przy temperaturze powietrza $15^{\circ} \mathrm{C}, 18^{\circ} \mathrm{C}$ i $21^{\circ} \mathrm{C}\left( \pm 1^{\circ} \mathrm{C}\right)$.

W wyniku przeprowadzonych badań stwierdzono, że wzrost temperatury powietrza $\mathrm{w}$ zakresie od $15^{\circ} \mathrm{C}$ do $21^{\circ} \mathrm{C}$ wplyną na przyspieszenie procesu ukorzeniania i istotne zwiększenie liczby korzeni formowanych na sadzonkach obu gatunków roślin. Wyższa temperatura wody $\left(24^{\circ} \mathrm{C}, 27^{\circ} \mathrm{C}\right)$ wywierała korzystny wpływ na tempo procesu ukorzeniania, natomiast nie miała wpływu na średnią liczbę korzeni formowanych na sadzonkach chryzantem i róż. Wzrost zarówno temperatury wody jak i powietrza powodował istotne zwiększenie tempa wzrostu wydłużeniowego korzeni, a tym samym podwyższenie ich świeżej i suchej masy. Odwrotny był wpływ temperatury wody na rozwój pakków śpiących na sađzonkach róż. Wzrost temperatury $w$ zakresie od $21^{\circ} \mathrm{C}$ do $27^{\circ} \mathrm{C}$ mial wplyw na zmniejszenie liczby wybitych pąków śpiących. 